Article

\title{
Responses of Macroinvertebrate Communities to Hydromorphological Restoration of Headwater Streams in Brittany
}

\author{
Gbenga E. Omoniyi ${ }^{1,2}\left(\mathbb{D}\right.$, Christophe Piscart ${ }^{1}$ (D), Laura Pellan ${ }^{1}$ and Benjamin Bergerot ${ }^{1, *}$ (D) \\ 1 Univ Rennes 1, CNRS, ECOBIO-UMR 6553, F-35000 Rennes, France; \\ gbenga.omoniyi@univ-rennes1.fr (G.E.O.); christophe.piscart@univ-rennes1.fr (C.P.); \\ lorapellan@gmail.com (L.P.) \\ 2 Department of Biological Sciences, Alex-Ekwueme Federal University, Ndufu-Alike Ikwo, \\ Abakaliki 482131, Nigeria \\ * Correspondence: benjamin.bergerot@univ-rennes1.fr; Tel.: +33-2-23-23-56-16
}

check for updates

Citation: Omoniyi, G.E.; Piscart, C.; Pellan, L.; Bergerot, B. Responses of Macroinvertebrate Communities to Hydromorphological Restoration of Headwater Streams in Brittany. Water 2022, 14, 553. https://doi.org/ 10.3390/w14040553

Academic Editors: Philippe Usseglio-Polatera, Olivier Dézerald and Benjamin Alric

Received: 31 December 2021

Accepted: 8 February 2022

Published: 12 February 2022

Publisher's Note: MDPI stays neutral with regard to jurisdictional claims in published maps and institutional affiliations.

Copyright: (c) 2022 by the authors. Licensee MDPI, Basel, Switzerland. This article is an open access article distributed under the terms and conditions of the Creative Commons Attribution (CC BY) license (https:// creativecommons.org/licenses/by/ $4.0 /)$.

\begin{abstract}
Indices of fauna communities, including macroinvertebrates, have been widely used as indicators of environmental changes in streams with great success. However, in the evaluations of in-stream restorations, results from the deployment of macroinvertebrate community indices as bio-indicators have been inconclusive, with scanty evidence for success. This study aims to determine if in headwater streams, and particularly according to the type of in-stream restoration studied (i.e., suppression of concrete pipe), bio-indicators based on macroinvertebrate can be relevant. We monitored three headwater stream reaches where artificial structures constituting hydromorphological impairments to the streams were removed. We collected macroinvertebrate samples from impacted stream sections and control sites established along the streams. Samples were collected before and after the restoration activities, in a before-after-control-impact (BACI) study design. We used two macroinvertebrate-based multimetric tools (I2M2 and ERA) to evaluate the ecological status of the streams, based on macroinvertebrate community indices, and to identify the relative contributions of watershed anthropic pressures to the ecological status. We found that the removal of the artificial structures and the restoration of natural flow were successful in reducing clogging. However, only taxonomic richness showed a positive significant change. The results indicate that the presence of confounding factors, not addressed by the restoration works, may have been responsible for this minimal success in biodiversity recovery. Although the multimetric assessment tools were able to differentiate between streams and disentangle the effects of multiple pressures contributing to degradation in the streams, they were limited to a level below the watershed scale. Our results showed that for a better outcome for macroinvertebrate biodiversity improvement, methods of in-stream restorations must consider the multiple pressures contributing to the degradation of fauna communities in watersheds.
\end{abstract}

Keywords: biodiversity; restoration; assessment tools; macroinvertebrate

\section{Introduction}

Anthropogenic activities have resulted in the widespread degradation of ecosystems worldwide, causing significant alteration to their ecological status [1,2]. The balance between spatial and temporal species occurrences is also being altered across all major ecosystems by human activities, in concert with the global change in climate [3]. Lotic systems, in particular, have seen increasingly severe impacts as a result of extensive landuse changes and river modifications [4-8].

According to the European Water Framework Directive (WFD), almost $60 \%$ of European surface waters, including rivers and streams, do not meet the criteria for a good ecological status [9]. Dams and other forms of hydraulic structures built across flow channels have severely altered the natural ecology of rivers [10,11]. For example, due to the 
reduction in flow current, there is impairment to sediment transport, with the consequent clogging of interstitial spaces upstream of the blocking structure [12]. Migratory species are impeded and species with an affinity for high flow currents are replaced by species with a preference for low flow currents $[13,14]$.

To reverse this trend and improve the good ecological status of European streams, the WFD requires member states of the EU to implement appropriate management and restoration programs on impacted streams $[15,16]$. Consequently, the past decades have documented an increasing number of restoration works on hitherto degraded streams [17-19].

Ecological restoration can be described as the process of assisting the recovery of damaged, degraded, or destroyed ecosystems [20,21]. Restoration activities may differ, depending on the source of the degradation and the size (or type) of the targeted stream reach. However, the primary focus of most schemes has been the in-stream restoration of habitats [18,22-24]. The underlining assumption is that habitat restoration will lead to an increase in biodiversity and ultimately, the improvement of the ecological 'health' of such streams [25-27]. Consequently, biodiversity metrics of fauna have been the most common ecological indicators deployed for the assessment of stream restoration [28-30]. While postrestoration assessments are generally not widespread $[17,24]$, the few studies that assessed biodiversity after restoration have recorded a limited recovery of biodiversity [26,31].

Due to the dearth of information and the peculiarities of the nature of degradation [32], the nature of ecological recovery remains uncertain in restored headwater streams [32,33]. Indeed, most post-assessment work on restored streams focused on large streams and rivers that represent only a small number of sites restored each year. For example, Zaidel et al., [34] reported that there are more than 90,000 dams in the USA, but if smaller dams are taken into account, the number reaches probably two million. In France, the national database on obstacles to water flow referenced 121,540 obstacles in 2021 [35]. Of these, only $0.5 \%$ have a waterfall height of more than $10 \mathrm{~m}$, while $74 \%$ have a waterfall height of less than $1 \mathrm{~m}$. Consequently, the vast majority of hydromorphological restoration operations are carried out on small structures in the headwaters. These structures act as barriers between the stream channels and their riparian zones; impair flow connectivity between the upstream and downstream reaches, especially during base flow; could potentially constitute a barrier to the migration of fauna; cause the clogging of the substrate upstream, due to fine sediment accumulation [36-39]. They are, however, rarely studied, both in terms of impact and in terms of response to restoration [38-40].

Structural metrics, such as indicator species, species diversity, richness or composition of communities, including those of macroinvertebrates, are frequently used for bio-assessment, because species can be lost or replaced in response to environmental stressors $[19,24,41-45]$. However, most assessment efforts have only reported scanty changes in diversity resulting from restoration, and diversity metrics have shown little difference between restored and unrestored streams $[8,19,26,29,46,47]$. We set out to determine whether this will be different in the headwaters of streams in response to hydromorphological restoration related to the removal of small-scale obstacles.

Following the WFD, new macroinvertebrate monitoring tools emerged [48]. The WFD requires that bioassessment methods evaluate the ecological status of water bodies, by comparing biological quality elements between an observed versus a reference situation [49,50]. In France, the IBGN method (indice biologique global normalisé) has been used at the national scale since 1992 and was revised in 2004 . However, it was no longer satisfying due to severe inconsistencies with the WFD (for further details, see [28]). Mandated by the French Ministry of Environment (MEDDTL), a new multimetric index was designed for the invertebrate-based ecological assessment of French wadeable streams (I2M2, [28]). This index incorporates both taxonomic characteristics and biological traits of benthic macroinvertebrates and is able to identify impaired reaches for 17 anthropogenic pressure categories. This index responds efficiently to the effects of physical, chemical, and hydromorphological pressures [51], as a proxy of site ecological status [52], and it is more robust than the IBGN [53]. Today, managers urgently need tools that can support them 
in the decision-making process for protecting and restoring river ecosystems, either for biodiversity conservation or the amelioration of anthropic stressors.

Due to multiple factors at play, the literature does not provide an overall consensus on the effect of stream restoration on invertebrates. In this context, we investigated the response of the promising I2M2 to the removal of small artificial hydraulic structures (i.e., concrete pipes) in three French headwater streams.

We analyzed the impact of removing concrete pipes in three headwater streams presenting different levels of anthropogenic disturbance, before and for two years after the removal of the structures. The first objective was to analyze the suitability of standard bioindicators (I2M2) developed for the WFD, to highlight the efficiency of the hydromorphological restoration and to check if the probabilities of impact by different anthropic pressures, identified by the Ecological Risk Assessment (ERA) tool (based on the biological characteristics of benthic macroinvertebrate communities, $[54,55]$ ), could be useful to weight multiple anthropogenic pressures influencing biotic assemblages in streams, before and after restoration. The second objective was to test if the lack of consensus on the efficiency of hydromorphological restoration in the literature may be related to the intensity of stress in the streams before restoration (e.g., low, intermediate, or high intensity of the disturbance). More specifically, we questioned if restoration is more efficient in highly impaired streams than in streams with low impairment. The third objective was to analyze the impact of hydromorphological impairments and the impacts of other anthropic pressures in the response of macroinvertebrate communities. This approach presents a unique opportunity to estimate the separate role of chemical pollution and the hydromorphological degradation on the impacts of multiple stressors in streams.

\section{Materials and Methods}

\subsection{Study Sites}

Three restored headwater stream reaches in Brittany region, North-Western France were followed for this study in a before-after-control-impact (BACI) design. The region consists of a patchy landscape with forests, pastures, crop cultures, and farming zones, exhibiting a wide range of agricultural practices [56]. Three reaches, belonging to 3 streams with differing anthropogenic pressures were selected (Figure 1). Land use around each reach has been assessed through the percentage of natural and anthropic land use cover as provided for in 2018 by the Corine Land Cover database [57] (Table 1).

Traou Breuder $\left(48^{\circ} 27^{\prime} 30.2^{\prime \prime} \mathrm{N} 3^{\circ} 21^{\prime} 43.7^{\prime \prime} \mathrm{W}\right)$ is a first-order stream with a catchment weakly impacted by agricultural practices (mainly pasture). This site was restored in the summer of 2018 by the removal of a concrete pipe. The second reach is located on the Pontplaincoat stream, a second-order stream impacted by pasture, crop fields, and industrial cow and pig farming. The restoration done in autumn 2019 consisted of the removal of two successive weirs ( 1 and $1.5 \mathrm{~m}$ high) $\left(48^{\circ} 41^{\prime} 08.3^{\prime \prime} \mathrm{N} 3^{\circ} 48^{\prime} 23.4^{\prime \prime} \mathrm{W}\right.$ upstream and $48^{\circ} 41^{\prime} 25.7^{\prime \prime} \mathrm{N} 3^{\circ} 48^{\prime} 54.2^{\prime \prime} \mathrm{W}$ downstream). The last reach is located on the Malville stream $\left(47^{\circ} 55^{\prime} 06.0^{\prime \prime} \mathrm{N} 2^{\circ} 24^{\prime} 36.4^{\prime \prime} \mathrm{W}\right)$ in a sub-urban watershed highly impacted by its hydromorphology, hydrology, and chemistry. The reach was partially restored in autumn 2018 by the removal of a concrete pipe. However, the restoration was incomplete because of the presence of a second concrete pipe downstream which cannot be removed (exit way of a motorway).

We defined three sampling sites per stream. The "impacted" site, located just upstream of the location of the artificial structure; a "control" (or reference) site, located between 30 and $200 \mathrm{~m}$ upstream of the impacted site; a "downstream" site, a few meters downstream of the artificial structure (Figure 2). 


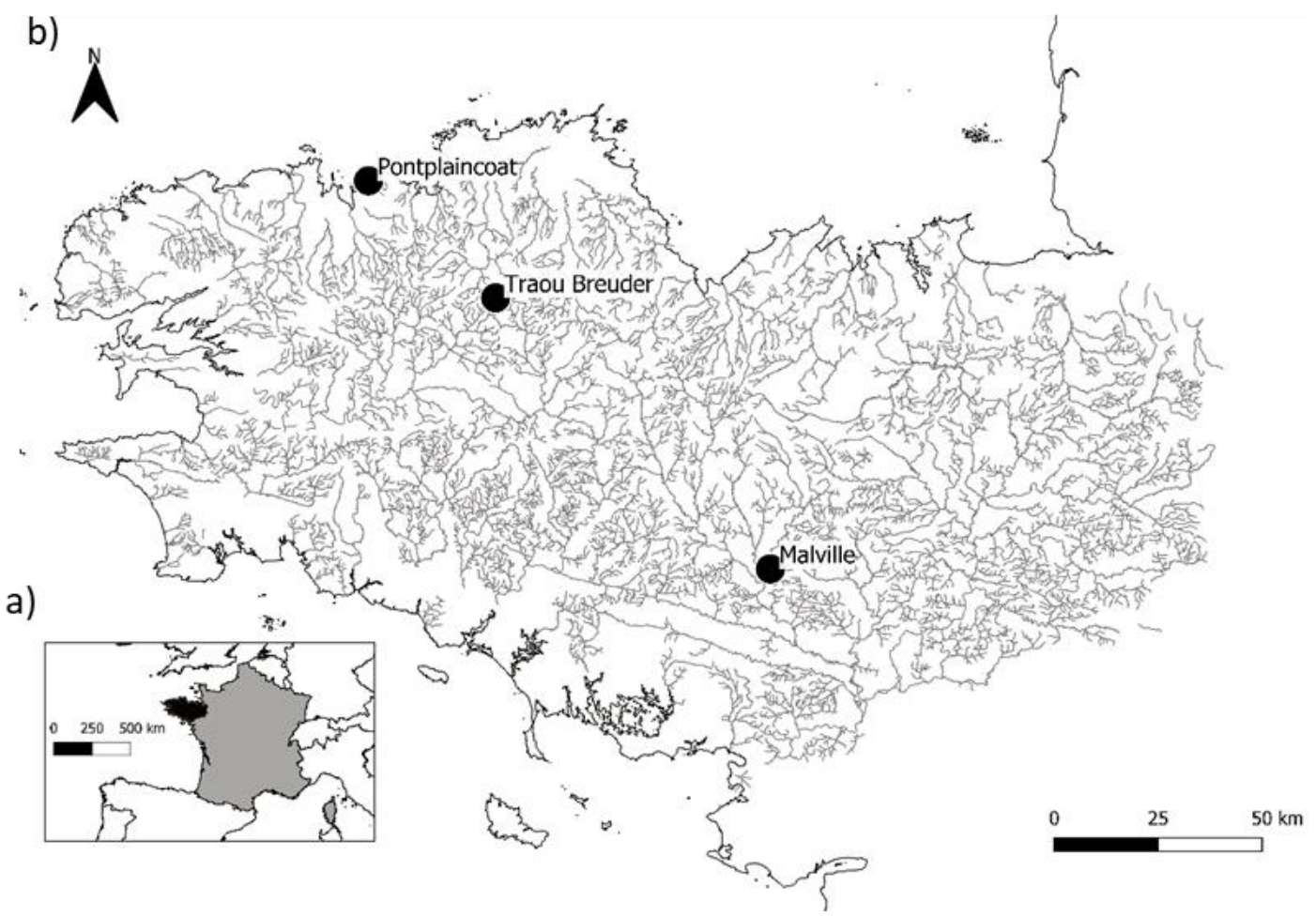

Figure 1. Maps of (a) France (grey) with Brittany region (black), and (b) Brittany region showing the locations of the 3 restoration sites. Grey lines represent the stream networks of the region.

Table 1. Proportion (\%) of land use per watershed according to Corine Land Cover 2018 data.

\begin{tabular}{lccc}
\hline Land Use & Traou Breuder & Pontplaincoat & Malville \\
\hline Artificial surfaces & 2.6 & 9.5 & 12.5 \\
Agricultural areas & 80.0 & 78.3 & 78.2 \\
Forest and semi-natural areas & 17.4 & 11.7 & 9.3 \\
Wetlands & 0.0 & 0.45 & 0.0 \\
\hline
\end{tabular}

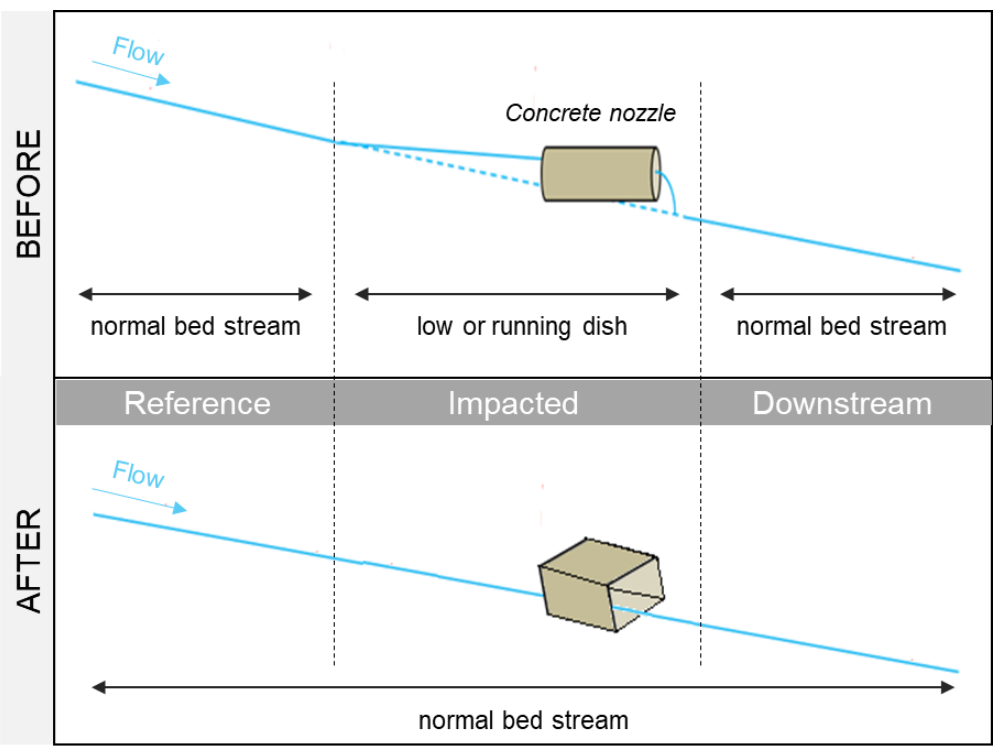

Figure 2. Channel profile before (upper part) and after (lower part) the replacement of the concrete pipe. The shaded areas delimited by dotted lines represent the three sampling sites (i.e., reference, impacted, and downstream) for each stream. 


\subsection{Macroinvertebrate Sampling}

For an efficient quantitative assessment and to ensure that cryptic species were not left out, a standardized Surber net sampler $\left(0.05 \mathrm{~m}^{2}\right.$ and $0.5 \mathrm{~mm}$ mesh size $)$ was used for benthic macroinvertebrates sample collection on all sites both before and after restoration works. Samples were collected in autumn and spring before restoration work and for 2 years in each case after the restoration. Twelve sample units per site (i.e., reference, impacted, downstream, Figure 2), following a standardized multi-habitat sampling protocol (MultiHabitat Sampling, norm XP T 90-333 in [58]) with consideration for the relative coverage and fauna-hosting capacity of substrates, were performed during every sampling campaign. All invertebrates were stored in $96 \%$ alcohol and later sorted and identified to the least taxonomic level possible, which for most groups is the genus level except Oligochaeta and Diptera, which were identified to the family/subfamily level.

\subsection{Data Analyses}

\subsubsection{French Multimetric Index (I2M2) and Bioindicators}

We estimated the ecological status of the streams using the French multimetric index (I2M2) for the invertebrate-based ecological assessment of French wadeable streams [28]. We used the I2M2 because it fulfills the WFD requirements. It significantly improves the detection of impaired reaches when compared to other multimetric indexes and it takes into account pressure-impact relations for a high number of pressure categories (including both water quality and habitat degradation) and considers both taxonomic characteristics and biological traits of benthic macroinvertebrate assemblages [28]. The I2M2 expresses ecological status in terms of the Ecological Quality Ratio (EQR). The EQR corresponds to the difference between the observed situation and the reference situation. This ratio is a number between zero and one, with values from 'reference' conditions close to one and values from impacted reaches with 'bad' ecological status close to zero [28]. The I2M2 integrates a suite of physico-chemical and hydromorphological pressures by assigning weight based on the specific pressure-type combination of five taxonomy-based and trait-based metrics of macroinvertebrates. The I2M2 score is divided into five categories (high, good, moderate, poor and bad with the threshold values $0.870 ; 0.733 ; 0.488$ and 0.244 , respectively).

We calculated five taxonomy-based and trait-based metrics as the ASPT (Average Score Per Taxon) score [59], the taxonomic richness (calculated at the reach level following taxonomic identification levels recommended by [60]), the Shannon diversity index [61], the relative abundance of ovoviviparous species and the relative abundance of the polyvoltine species [62].

We tested if the I2M2 score and the five taxonomy-based metrics differed significantly between streams, sampling session (i.e., before restoration, the first and the second year of monitoring after restoration), sites (i.e., reference, impacted, and downstream section), and their interactions. We performed a type III analysis of variance (ANOVA) using the package 'car' due to the presence of the interaction factor [63]. The normal distribution of the residuals of the model was checked using the Shapiro-Wilk test of normality. When a factor was significant, we performed Tukey post-hoc tests for pairwise comparisons. To illustrate the impact of the restoration, we also computed the deviations of the mean values of the taxonomic metrics at each site from the mean values at the control site for each sampling date.

\subsubsection{Macroinvertebrate Community Analyses and Ecological Risk Assessment Tool (ERA)}

To study the changes in macroinvertebrate community structures between the "control", "impacted" and "downstream" sites, we performed type III PERMANOVAs under a reduced model for each stream with Bray-Curtis similarities and "site" as the fixed factor and "restoration" as the second factor (with 2 modalities "before" and "after" restoration).

We also used the Ecological Risk Assessment (ERA) tool [54,55] to establish the probabilities of impact by different anthropic pressures from the biological characteristics of benthic macroinvertebrate communities before and after restoration. This diagnostic tool 
aims to identify the potential weight of individual anthropogenic pressures influencing biotic assemblages in streams under a multiple pressure scenario [54]. Models were built for different types of pressures related either to water quality (based on the [64] assessment grids) or to the quality of the physical habitat at the level of the watercourse and its catchment. Models were constructed following the procedure described in [55]. The water quality degradation pressure categories considered were organic matter, nitrogen compounds (except nitrates), nitrates, phosphorous compounds, pesticides, and polycyclic aromatic hydrocarbons. The habitat degradation pressure categories considered were transportation facilities, riverine vegetation, hydrological instability, urbanization, clogging risk, and catchment anthropization. All the details about pressure categories are provided in [28]. The ERA tool retains the anthropic pressures with satisfactory performance among the 17 pressures [55].

To investigate the different anthropic pressures identified by the ERA tool before and after the restoration, we firstly conducted a principal component analysis (PCA) on the anthropic pressures retained among the 17 by the ERA tool as variables with the 'ade4' package [65]. The PCA enabled us to give a first descriptive approach since we also projected the I2M2 index and factors related to the five taxonomy-based metrics as supplementary variables (which do not influence the PCA). We also did a pairwise comparison of the I2M2 index and factors related to the five taxonomy-based metrics with the different anthropic pressures identified by the ERA tool using Spearman correlation analysis to test the relationship between the ecological status of the streams, macroinvertebrate community structure, and the environmental pressures respectively.

To analyze the effect of restoration for each site, we decided to work on the PCA coordinate projections on the PC1 and PC2 axes. We tested if the projection of the points on the first two dimensions significantly differed between session (i.e., before restoration, the first and the second year of monitoring after restoration), sampling site (i.e., reference, impacted, and downstream sites), and their interactions. We performed a two-way analysis of variance (ANOVA) with site as random effect using the 'lmer4' package [66] followed by a normal distribution check of the residuals of the model using the Shapiro-Wilk test of normality. When a factor was significant, we performed the Tukey post-hoc tests using 'emmeans' package [67] to characterize the differences.

\section{Results}

\subsection{Efficiency of Bioindicators}

I2M2 and associated metrics confirmed the difference and the intensity of stress between the three streams (Figure 3). The Traou Breuder stream was the stream with the highest EQR for all metrics. The Malville stream presented the lowest EQR for I2M2, ASPT and richness, and similar values to Pontplaincoat for Shannon diversity, ovoviviparity, and polyvoltinism. The Pontplaincoat had intermediate values of EQR. Moreover, before restoration, the ecological status of streams, as assessed through the values of I2M2, ranged from poor (Malville and Pontplaincoat streams) to moderate (Traou Breuder) (Table 2).

After restoration, the overall results per stream were strongly heterogeneous (Table 2). Traou Breuder presented a slight increase from moderate to good ecological status after two years (Table 2), whereas Malville changed from poor to bad after two years. Pontplaincoat's ecological status remained classified as poor.

The ANOVA results showed a significant stream effect on the I2M2 and the five taxonomy-based metrics (Table 3). Except for the richness, which presented a significant difference according to the session, no significant differences were found for the I2M2 and the five taxonomy-based and trait-based metrics, according to the session, the sampling period, or their interaction (Table 3). 

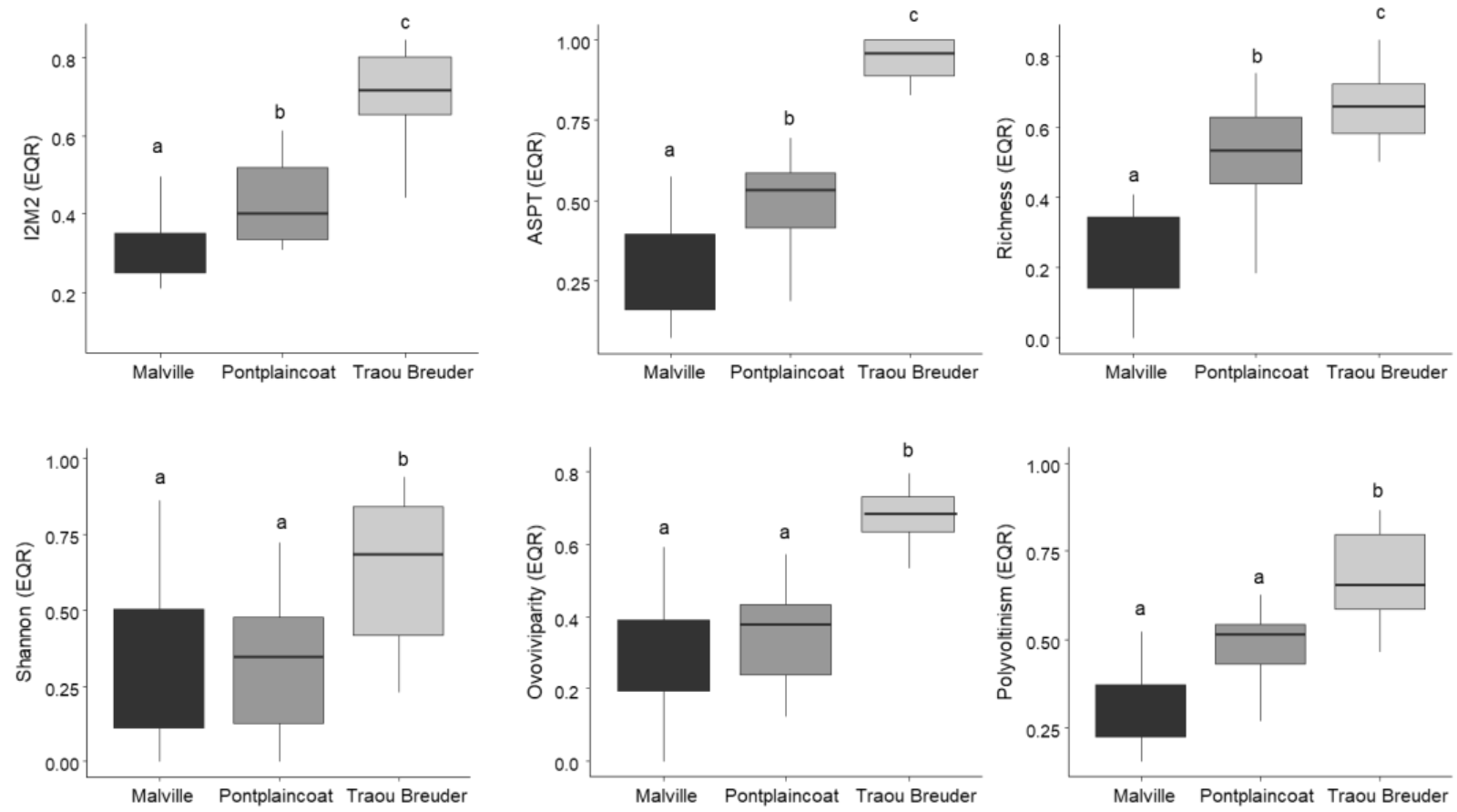

Figure 3. Boxplots representing the I2M2 median values ( \pm 25 th and 75 th percentile) and the five taxonomy-based metrics in terms of Ecological Quality Ratio (EQR) in the three streams. Different lower-case letters represent significant differences according to the results of Tukey's posthoc tests (ASPT: Average Score Per Taxon; Richness: taxonomic richness and Shannon: Shannon's diversity index; Ovoviviparity: relative abundance of ovoviviparous species; polyvoltinism: relative abundance of the polyvoltine species).

Table 2. Ecological status (I2M2) of the three streams before and after restoration (Before: before restoration; after1: first year of monitoring after restoration; after2: second year of monitoring after restoration) according to the five taxonomy-based and trait-based metrics. The threshold values used to define the ecological status classes are those from [28]. These threshold values are respectively: $0.870 ; 0.733 ; 0.488 ; 0.244$. Values are expressed as mean \pm variance in terms of Ecological Quality Ratio (EQR).

\begin{tabular}{cccc}
\hline Site & Session & I2M2 (EQR) & Ecological Status \\
\hline \multirow{3}{*}{ Malville } & Before & $0.325 \pm 0.001$ & Poor \\
& After1 & $0.426 \pm 0.024$ & Poor \\
& After2 & $0.217 \pm 0.005$ & Bad \\
\hline \multirow{3}{*}{ Pontplaincoat } & Before & $0.462 \pm 0.017$ & Poor \\
& After1 & $0.448 \pm 0.014$ & Poor \\
& After2 & $0.405 \pm 0.011$ & Poor \\
\hline \multirow{3}{*}{ Traou Breuder } & Before & $0.706 \pm 0.013$ & Moderate \\
& After1 & $0.666 \pm 0.001$ & Moderate \\
& After2 & $0.814 \pm 0.000$ & Good \\
\hline
\end{tabular}

For taxonomic richness, the values showed a significant difference (Table $3 ; p=0.05$ ) between the before restoration session $(0.61 \pm 0.03)$ and the two years after restoration session $(0.37 \pm 0.05)$. There was no significant difference between the one year after restoration session $(0.45 \pm 0.04)$, the before restoration session, and the two years after restoration session. The deviation from the mean taxonomic richness of the control site significantly changed between streams (Figure $4 ; p<0.001)$, sites $(p=0.040)$, and the hydromorphological restoration significantly increased the number of species $(p=0.002)$. However, we did not observe any significant interaction between the restoration and any 
other factors, neither with stream $(p=0.194)$ nor with site $(p=0.336)$. Moreover, the deviation from the control site was the highest in Pontplaincoat, in comparison with Traou Breuder and Malville ( $p<0.001$ and $p=0.033$, respectively).

Table 3. Results of the ANOVA for the effects of stream, session, the sampling site and their interaction on the I2M2 and the five taxonomy-based metrics (Df = degree of freedom; F: F value; $p$ : $p$-value, bold when significant; ASPT: Average Score Per Taxon; Richness: taxonomic richness and Shannon: Shannon's diversity index; Ovoviviparity: relative abundance of ovoviviparous species; polyvoltinism: relative abundance of the polyvoltine species).

\begin{tabular}{|c|c|c|c|c|c|c|c|c|c|c|c|c|c|}
\hline & \multirow[b]{2}{*}{ Df } & \multicolumn{2}{|c|}{ I2M2 } & \multicolumn{2}{|c|}{ ASPT } & \multicolumn{2}{|c|}{ Richness } & \multicolumn{2}{|c|}{ Shannon } & \multicolumn{2}{|c|}{ Ovoviviparity } & \multicolumn{2}{|c|}{ Polyvoltinism } \\
\hline & & $\mathbf{F}$ & $p$ & $\mathbf{F}$ & $p$ & $\mathbf{F}$ & $p$ & $\mathbf{F}$ & $p$ & $\mathbf{F}$ & $p$ & $\mathbf{F}$ & $p$ \\
\hline Stream & 2 & 45.63 & $<0.001$ & 109.2 & $<0.001$ & 36.94 & $<0.001$ & 8.02 & $<0.001$ & 24.42 & $<0.001$ & 10.17 & $<0.001$ \\
\hline Session & 2 & 1.26 & 0.29 & 1.31 & 0.28 & 3.55 & 0.04 & 2.54 & 0.09 & 1.19 & 0.31 & 0.21 & 0.81 \\
\hline Site & 2 & 0.14 & 0.87 & 0.59 & 0.56 & 0.91 & 0.41 & 0.25 & 0.78 & 0.48 & 0.62 & 0.001 & 0.99 \\
\hline Session $\times$ site & 4 & 0.51 & 0.73 & 0.71 & 0.59 & 0.75 & 0.56 & 0.37 & 0.83 & 0.62 & 0.64 & 0.58 & 0.67 \\
\hline
\end{tabular}

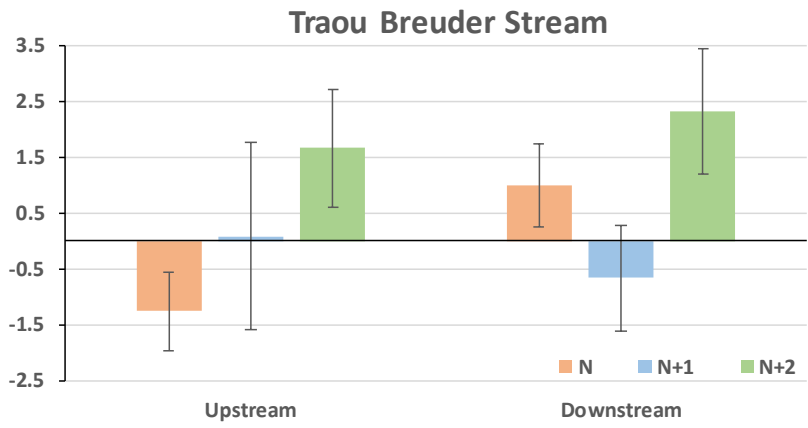

Malville Stream

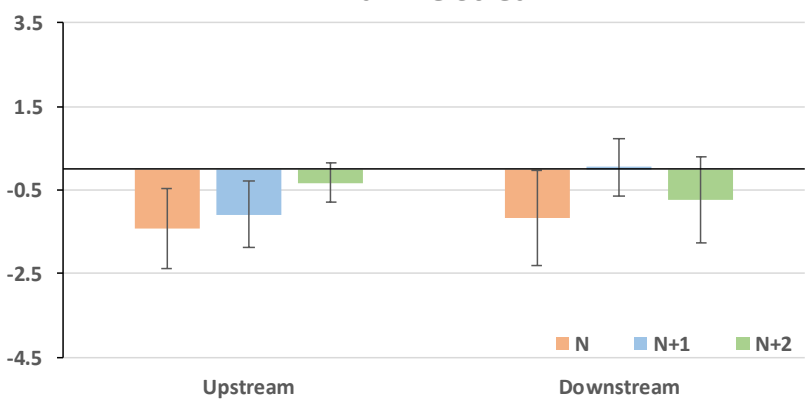

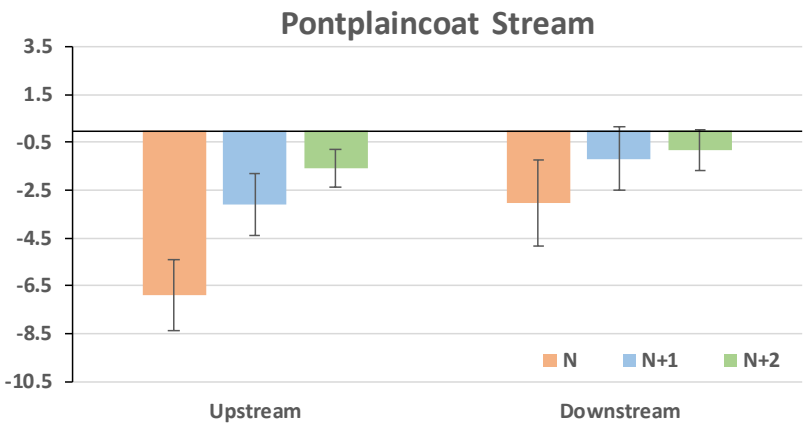

Pontplaincoat Stream

Figure 4. Annual mean deviation $( \pm \mathrm{SE})$ from the mean taxonomic richness in the "control" sites before and after restoration ( $\mathrm{N}$ : before restoration; $\mathrm{N}+1$ : first year of monitoring after restoration; $\mathrm{N}+2$ : second year of monitoring after restoration).

\subsection{Assessment of Community Structure}

The results of Bray-Curtis similarities of macroinvertebrate communities between each sampling site in the streams were very heterogeneous, before restoration and after restoration (Table 4). Before restoration, in Traou Breuder, there was no difference in the Bray-Curtis similarities between the macroinvertebrate community in the control and the upstream $(p=0.185)$ or downstream sites $(p=0.084)$, but a difference between the upstream and the downstream section $(p=0.034)$. In the Pontplaincoat, the upstream section was significantly different from the control $(p=0.001)$ and downstream section $(p=0.001)$, but control and downstream sections were marginally different $(p=0.064)$. In the Malville Stream, the control and upstream sections were similar $(p=0.117)$, but the downstream section significantly differed from the other sections ( $p$ values $=0.001$ ). 
Table 4. Results of PERMONAVAs on the Bray-Curtis similarities (BCs) between macroinvertebrate communities before and after restoration (Before: before restoration; after1: first year of monitoring after restoration; after2: second year of monitoring after restoration; $\mathrm{C}=\mathrm{Control}$ site; $\mathrm{up}=\mathrm{upstream}$ section and down = downstream section).

\begin{tabular}{cccccccccccc}
\hline & & \multicolumn{3}{c}{ Traou Breuder Stream } & \multicolumn{2}{c}{ Pontplaincoat Stream } & \multicolumn{3}{c}{ Malville Stream } \\
\hline & & BCs & T & $p$ & BCs & T & $p$ & BCs & T & $p$ \\
\hline \multirow{2}{*}{ Before } & C/up & 43.8 & 1.304 & 0.084 & 36.6 & 2.621 & 0.001 & 43.4 & 1.245 & 0.117 \\
& C/down & 43.6 & 1.152 & 0.185 & 44.6 & 1.368 & 0.064 & 32.9 & 2.380 & 0.001 \\
& Up/down & 44.1 & 1.368 & 0.034 & 34.7 & 2.370 & 0.001 & 36.6 & 2.621 & 0.001 \\
\hline \multirow{2}{*}{ After 1 } & C/up & 47.0 & 1.141 & 0.214 & 41.0 & 1.573 & 0.02 & 39.4 & 1.073 & 0.304 \\
& C/down & 45.9 & 1.276 & 0.136 & 43.0 & 1.324 & 0.085 & 42.4 & 1.637 & 0.003 \\
& Ups/down & 44.0 & 1.529 & 0.027 & 41.0 & 2.017 & 0.002 & 42.9 & 1.172 & 0.16 \\
\hline \multirow{2}{*}{ After 2 } & C/up & 54.7 & 1.386 & 0.040 & 40.4 & 1.631 & 0.009 & 40.4 & 0.914 & 0.577 \\
& C/down & 57.2 & 1.000 & 0.379 & 38.7 & 1.362 & 0.051 & 39.4 & 1.077 & 0.296 \\
& Up/down & 54.5 & 1.496 & 0.033 & 36.3 & 1.769 & 0.003 & 38.6 & 1.208 & 0.155 \\
\hline
\end{tabular}

After restoration, all the differences between the sites disappeared after two years, remained similar in Pontplaincoat, but slightly increased in Traou Breuder (Table 4).

\subsection{Ecological Risk Assessment (ERA) Tool}

The ERA tool identified the following 12 anthropic pressures: transportation facilities, organic matter, nitrogen compounds, phosphorous compounds, hydrological instability, urbanization, pesticides, polycyclic aromatic hydrocarbons (PAH), clogging, nitrates, catchment anthropization, and riverine vegetation.

The first two principal components of the PCA explained, respectively, $55.5 \%$ and $25.5 \%$ of the total variance (Figure $5 \mathrm{~A}$ ). The first component was mainly explained by the following six anthropogenic pressures: clogging at $13.20 \%$, catchment anthropization at $12.06 \%$, nitrates at $11.73 \%$, PAH at $11.44 \%$, pesticides at $9.93 \%$, and urbanization at $9.88 \%$. The second component was mainly explained by five other anthropic pressures, as follows: transportation facilities at $21.29 \%$, organic matter at $21.06 \%$, nitrogen compounds at $17.33 \%$, phosphorous compounds at $7.29 \%$, and riverine vegetation at $8.76 \%$. The first principal component of the PCA is related to watershed chemical perturbations and sediment clogging, whereas the second principal component is related mainly to riparian vegetation and nutrients (Figure 5B).

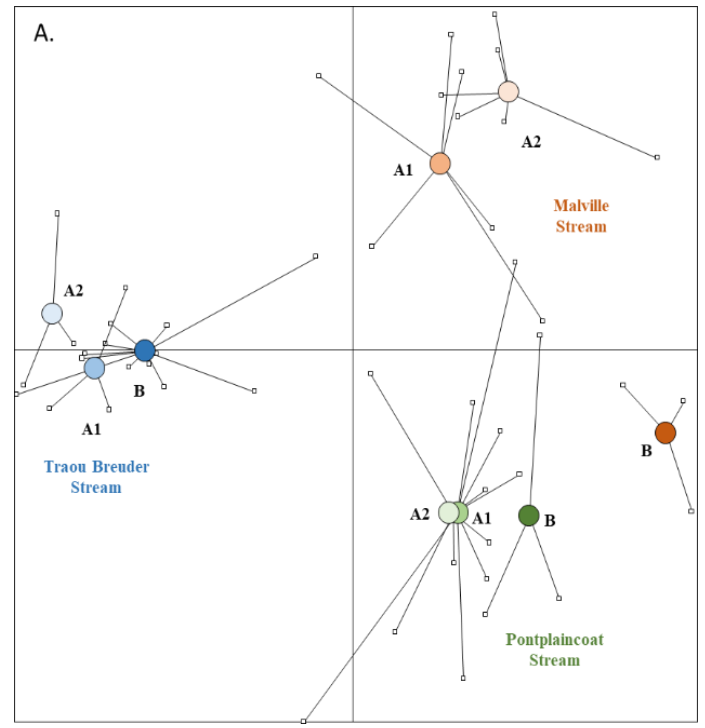

Figure 5. Cont. 


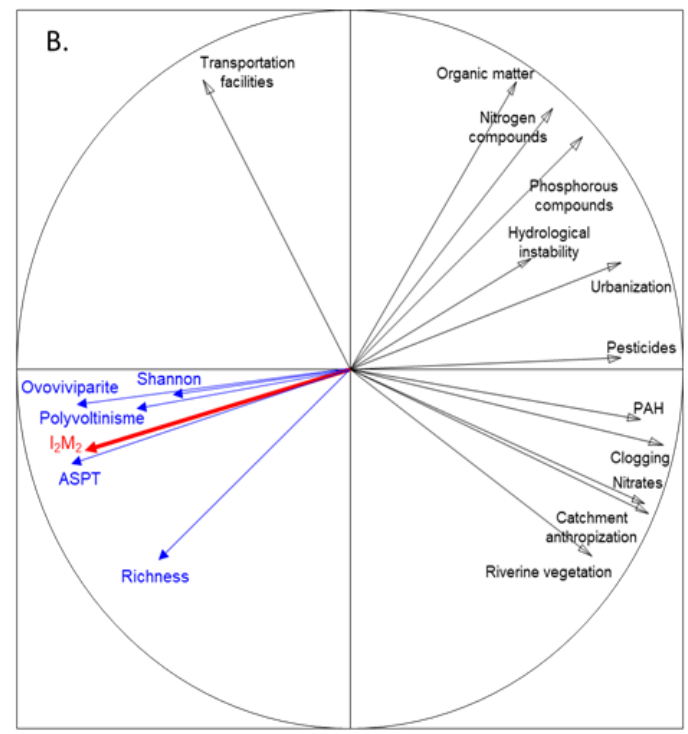

Figure 5. (A) Principal Component Analysis (PCA) of the three sites according to the different anthropic pressures identified by the ERA tool. The colored circles represent the barycenters of the sessions (Before: before restoration; A1: first year of monitoring after restoration; A2: second year of monitoring after restoration). (B) Correlation circle showing correlations among the 12 water quality and habitat degradation pressure categories retained (PAH: polycyclic aromatic hydrocarbons). The I2M2 (red arrow) and the five taxonomy-based metrics (blue arrows) are projected as quantitative supplementary variables (ASPT: Average Score Per Taxon, Richness: taxonomic richness, Shannon: Shannon's diversity index, Ovoviviparity: relative abundance of ovoviviparous species, polyvoltinism: relative abundance of the polyvoltine species).

These results were confirmed by the Spearman correlation tests (Figure 6). The I2M2 and the five associated metrics were significantly positively correlated. The six main anthropic pressures explaining the first axis of the PCA were also significantly positively correlated. Among the five main anthropic pressures explaining the second axis of the PCA, the organic matter, nitrogen compounds, and phosphorous compounds were highly positively and significantly correlated; riverine vegetation and transportation facilities were significantly negatively correlated.

The I2M2 and the five associated metrics showed significant negative correlations with the 11 anthropic pressures; only two non-significant relations occurred (top right part of Figure 6). Richness and Shannon indices did not correlate with the degradation from riverine vegetation and organic matter, respectively, and the transportation facilities, without any correlation, except with the ovoviviparity.

Before restoration, the probabilities of impact by the different anthropic pressures at Traou Breuder was relatively low, compared to the other two streams, and presented the highest ecological status, as suggested by the values of I2M2 and other metrics (Figure 5A). Pontplaincoat was located in the lower-right part of the PCA, mainly characterized by a high probability of clogging, catchment anthropization, strong nitrates inputs, and degradation of riverine vegetation. Finally, Malville, located at the right side of the axis, was characterized by a high probability of $\mathrm{PAH}$, clogging, nitrates, catchment anthropization, and pesticides.

There were no significant effects in terms of sampling sites (i.e., control, upstream and downstream section) and their interactions (Table 5). Tukey post-hoc tests showed that the position of the points significantly shifted one year after restoration and remained stable after two years (Figure 5). 


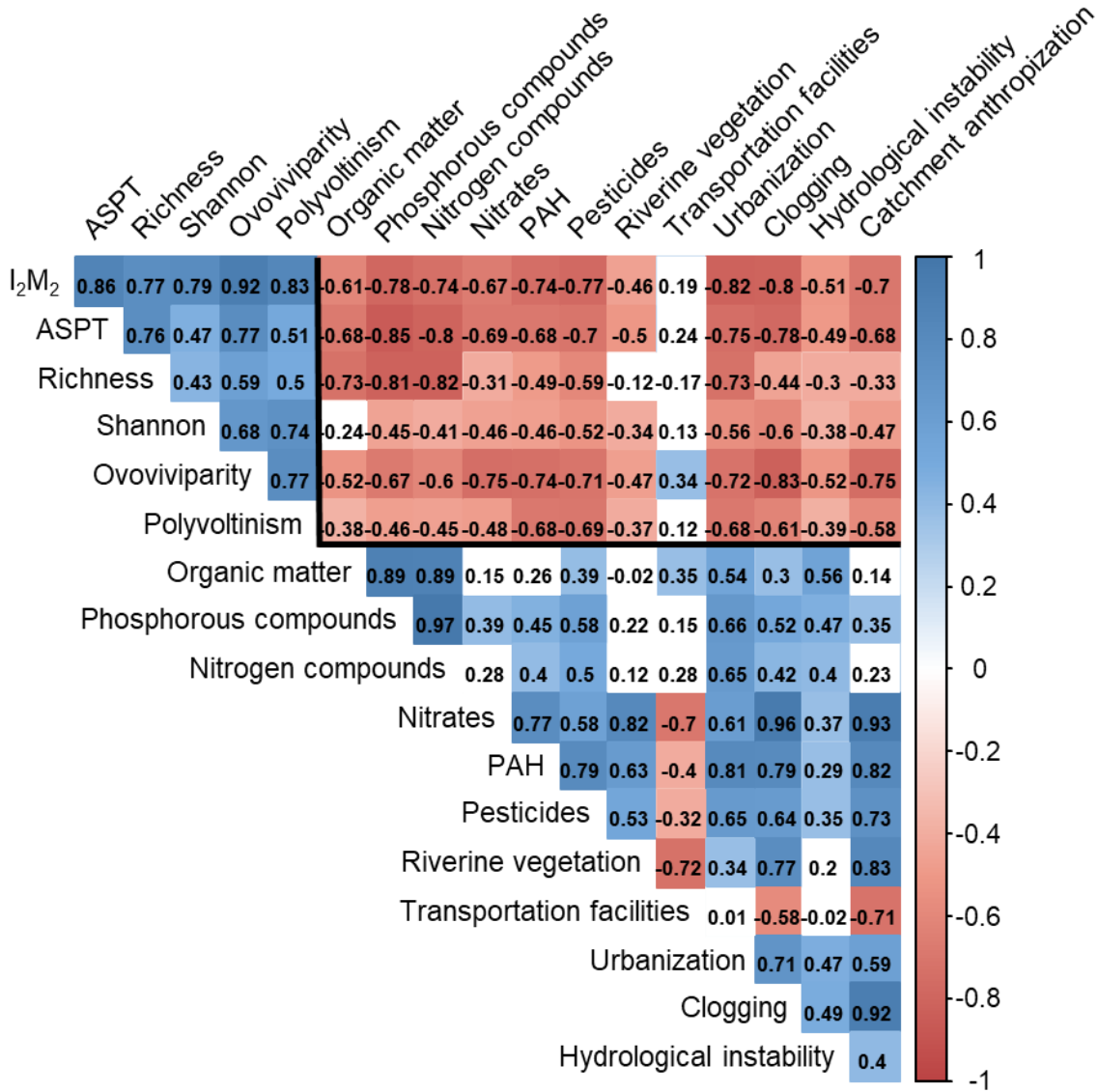

Figure 6. Spearman correlations between the I2M2, the five taxonomy-based and trait-based metrics in terms of Ecological Quality Ratio (ASPT: Average Score Per Taxon, Richness: taxonomic richness, Shannon: Shannon's diversity index, Ovoviviparity: relative abundance of ovoviviparous species, polyvoltinism: relative abundance of the polyvoltine species) and the 12 water quality and habitat degradation pressure categories (PAH: polycyclic aromatic hydrocarbons). The values represent the correlation coefficients. The colored squares represent the significant coefficients (red or blue, $p$-value $<0.05)$ according to the scale of the values indicated on the right of the correlogram. The black lines are used to visually separate the I2M2, the five taxonomy-based and trait-based metrics from the 12 water quality and habitat degradation pressure categories.

Table 5. Results of the two-way ANOVA with random effects for the stream, the session, the sampling site, and their interaction on the two first dimensions of the PCA (Df = degree of freedom; F: F value; $p$ : $p$-value).

\begin{tabular}{cccccc}
\hline & & & PC1 & & PC2 \\
\hline & Df & F & $p$ & F & $p$ \\
\hline Session & 2 & 8.10 & 0.001 & 2.89 & 0.07 \\
Site & 2 & 0.01 & 0.99 & 0.20 & 0.82 \\
Session $\times$ Site & 4 & 0.41 & 0.80 & 0.43 & 0.78 \\
\hline
\end{tabular}

After restoration, the position of Traou Breuder and Pontplaincoat slightly shifted toward the left side of the first axis, confirming a decrease in the probabilities of the impacts of anthropogenic pressures on the two streams. Malville was the most influenced watershed, with a strong shift in the probabilities of the different anthropic pressures before and after restoration. After restoration, the points shifted significantly toward the top right part of the factorial plan, which indicated a high probability of nutrient, organic 
matter compounds and hydrological instability, and a reduced probability of clogging, $\mathrm{PAH}$, and anthropization.

\section{Discussion}

Irrespective of the complexity of restoration projects [50], assessing the outcome of river restoration projects is vital for adaptive management, evaluating project efficiency, optimizing future programs, and gaining public acceptance [68]. Although subjective criteria exist [69], the development of indicators now makes it possible to evaluate the effects of restoration programs more objectively [70]. In France, the I2M2 was built on more than 1700 sites, designed to identify impaired reaches, and to be compliant with the European WFD [28,54], as it can be used as a proxy to assess the ecological status of rivers [52]. In this study, we went a step further, asking whether this index is also able to detect hydromorphological impacts on headwater streams under multiple pressures and the change in their ecological status after restoration. Associated to the I2M2, we also used the Ecological Risk Assessment (ERA) tool [54,55] to establish the probabilities of impact by different anthropic pressures from the biological characteristics of benthic macroinvertebrate communities, before and after restoration. The goal was to identify the potential weight of individual anthropogenic pressures, influencing biotic assemblages in streams under multiple pressure scenarios [54], in order to address the question of the efficiency of hydromorphological restoration, widely used in headwaters.

\subsection{Macroinvertebrate Communities and the Ecological Status of Headwater Streams Impacted by Hydromorphological Impairments}

There is a clear difference in the overall ecological status at the watershed scale, as depicted by the I2M2, which categorizes two streams (Malville and Pontplaincoat) as "poor" and Traou Breuder as "moderate". The streams also differ in the macroinvertebrate metrics. Three of these metrics (Shannon diversity index, Average Score Per Taxon (ASPT), and taxonomic richness) are taxonomic metrics, considered to be the simplest measure of diversity [71,72]. However, within the streams (i.e., at the reach scale), neither the ecological status nor the macroinvertebrate metrics showed any important difference between sampling sites. These results indicate that the I2M2 and its associated metrics failed to highlight the impacts of physical impairments, such as concrete pipes and weirs, at the reach scale, as there is no differentiation between "control", "upstream", and "downstream" sections before restoration. This is contradictory to a previous study, showing that I2M2 was negatively influenced by variables describing hydromorphology at the reach scale [52], where they considered hydromorphological factors at the reach scale. These factors are different from those investigated in our study. Our study focused on small impairments affecting watersheds (from 30 to $200 \mathrm{~m}$ long reaches). At this small scale, the dispersal of invertebrates by drift or by flight remains possible and may likely compensate for physical impacts [56].

\subsection{Ecological Status and Biodiversity Indices in Response to Hydromorphological Restoration}

We expected an improvement in the ecological status of restored sites after restoration (Hypothesis 1), and more specifically, we expected that the ecological status of the restored sites would be comparable to the reference conditions at the control sites. The ecological status of the streams changed positively only in Traou Breuder, from "Moderate" to "Good", but the status in Pontplaincoat remained "Poor" after restoration and changed from "Poor" to "Bad" in Malville. This result indicates that the estimation of the I2M2 -based ecological quality ratio in each stream is dependent on the totality of the factors (water quality, nutrient, hydromorphological, etc.) in the streams and not just hydromorphological changes [52].

Also, the I2M2 based taxonomic metrics show that only richness has a positive change after restoration, with the mean values of the impacted sites closest to reference conditions in each stream two years after restoration, and even exceeding the reference condition in Traou Breuder in the second year after restoration, while there is no observable change in diversity 
and other taxonomic indices. In Miller et al. [24], the authors also observed positive effects for in-stream restoration on macroinvertebrate richness and inconclusive effects on density. In addition, the PERMANOVA on the Bray-Curtis similarities indicates that there is no consistent pattern in the overall similarities in macroinvertebrate community structure between the control sites and the impacted sites in the streams, both before and after restoration. This scanty and inconsistent response in macroinvertebrate communities to in-stream restorations has been observed in previous studies $[24,26,45]$. Even in the stream where there is an observable improvement in the ecological status after restoration, only taxonomic richness has a corresponding significant increase with other indices, showing only minimal changes. One possible reason to explain this lack of robust response by macroinvertebrate communities to in-stream restorations is the presence of other stressors, which are not simultaneously addressed by most restoration strategies [26]. The removal of the artificial structures in the investigated streams in this study is expected to restore natural flow and enhance sediment transport, thus, improving the habitat conditions in the restored reaches. This strategy, however, has minimal to no effect on the other anthropic pressures (including water quality and nutrient load) present in the watersheds. This point is supported by our findings from the ERA tool, which reported the presence of multiple anthropic pressures in the three watersheds, both before and after restoration. In Malville, for example, the ERA result reported a reduced probability of clogging after restoration but a higher probability of nutrient and organic matter loading.

\subsection{Disentangling the Impacts of Multiple Anthropic Pressures on the Ecological Status and the Response of Macroinvertebrate Communities to Hydromorphological Restoration}

Every stream is subject to natural variations, of both the biotic and abiotic components [22,73]. The ability to maintain this variation at the permissible level for the continuous functioning of the system is inhibited in degraded streams, usually due to the presence of multiple stressors [74]. The unbundling of these stressors will be key to the proper and sustainable restoration of such a system. The simultaneous use of the ERA tool and the I2M2 multimetrics in our analyses presents the potential to be able to disentangle the impacts of the artificial structures from other anthropic pressures. Using the ERA tool, we identified the following 12 anthropic pressures: hydrological instability, urbanization, transportation facilities, catchment anthropization, riverine vegetation, clogging, organic matter, nitrogen compounds, phosphorous compounds, pesticides, polycyclic aromatic hydrocarbons (PAH) and nitrates, present at the watersheds at different probabilities of impact, before and after restoration. This is in addition to the impacts of the presence of the artificial structures before their removal. In this study, we found that the I2M2 and associated metrics generally have a negative relationship, with 10 of these anthropic pressures indicating that their presence adversely affects the ecological status of the streams and, consequently, the macroinvertebrate communities [75]. Moreover, the most important impacts suggested by the analysis of the probability of impacts for each stream (Figure 5) are consistent with the supposed impacts relating to the land use as a proxy for watershed scale conditions $[24,56,76]$. We equally found differentiation between the probability of impacts before and after restoration. Before restoration, the ERA tool clearly separates Traou Breuder from Malville and Pontplaincoat and highlights a gradient of anthropic pressures responsible for this difference. This is consistent with the nature and intensity of stress observed in those streams. After restoration, the probabilities of impact by different anthropic pressures, identified by the Ecological Risk Assessment (ERA) tool, decreased in Traou Breuder and Pontplaincoat, suggesting that the hydromorphological restoration can increase the overall quality of a watershed, even if other pressures (i.e., nutrient or chemical pollution) are still present. In Malville, there was a drastic change in the main anthropic pressures identified by the ERA tool. Before restoration, the main pressures identified were clogging, alteration of riverine vegetation, and anthropization of the catchment. After restoration, the main pressures became hydrological instability and organic matter. These changes are consistent with our observation of the stream after restoration, which had 
strong impacts of erosion and increased summer drying. The ERA tool is, hence, able to highlight not only the main visible pressure but also indicate the negative consequences of hydromorphological restoration. In addition, the results from the ERA tool indicate that the removal of the artificial structures in the streams is generally successful in removing the impact of clogging, which was the main identified impact from the presence of the structures [77,78], and this was most visible in Malville. However, the persistence of the impacts of chemical compounds and nutrient load in the watersheds, even after restoration, may have been responsible for the scanty improvement in macroinvertebrate biodiversity indices. Water quality has been shown to have more influence on the community structure of macroinvertebrates than other factors, including habitat availability [79-81].

\section{Conclusions}

The prediction and distinction of the effects of multiple potential stressors represent a serious practical need for prioritizing management options to efficiently enhance river reach ecological quality [82]. Our study highlights that the presence of these confounding factors can potentially limit the gains from hydromorphological restoration. Restoration works monitored in this study were done at the reach scale. Results showed that available macroinvertebrate-based assessment tools, including the I2M2 and the ERA, measuring the impacts of multiple pressures on the ecological status of streams, are most effective at the watershed scale [83]. Hence, despite observing significant differences between streams in most of the metrics, the contributions of the reach scale changes to these differences were not detected. Additional restoration measures, such as adding beneficial bank vegetation and macrophytes, sediment traps and meanders, were shown to improve the quality of rivers, even those stressed by nutrients and chemical pollution.

Author Contributions: Conceptualization, G.E.O., B.B. and C.P.; methodology, G.E.O., B.B. and C.P.; formal analysis, G.E.O., B.B. and C.P.; investigation, All; resources, B.B. and C.P.; data curation, G.E.O. and L.P.; writing-original draft preparation, G.E.O., B.B. and C.P.; writing-review and editing, all; supervision, B.B. and C.P.; project administration, C.P. All authors have read and agreed to the published version of the manuscript.

Funding: This research was funded by the Brittany Region throughout the project BERCEAU (20192021). This work is part of the PhD thesis of the first author.

Institutional Review Board Statement: Not applicable.

Informed Consent Statement: Not applicable.

Data Availability Statement: Not applicable.

Acknowledgments: We thank Maeva Delmotte, who assisted in samplings and identification of macroinvertebrates, and a special thanks to the site managers Vincent Guizouarn (Lannion-Trégor Communauté, Traou Breuder Stream), Sébastien Le Goff (Syndicat Mixte du Trégor, Pontplaincoat Stream), and Sébastien Noblet (Syndicat Mixte du Grand Bassin de l'Oust, Malville Stream), who assisted us in the selection of sites and realized restoration actions.

Conflicts of Interest: The authors declare no conflict of interest. The funders had no role in the design of the study; in the collection, analyses, or interpretation of data; in the writing of the manuscript, or in the decision to publish the results.

\section{References}

1. Vitousek, P.M.; Mooney, H.A.; Lubchenco, J.; Melillo, J.M. Human Domination of Earth's Ecosystems. Science 1997, 277, 494-499. [CrossRef]

2. Dobson, A.P.; Bradshaw, A.D.; Baker, A.J.M. Hopes for the Future: Restoration Ecology and Conservation Biology. Science 1997, 277, 515-522. [CrossRef]

3. Dirzo, R.; Young, H.S.; Galetti, M.; Ceballos, G.; Isaac, N.J.B.; Collen, B. Defaunation in the Anthropocene. Science 2014, 345, 401-406. [CrossRef]

4. Newson, M.D.; Boon, P.J.; Calow, P.; Petts, G.E. River Conservation and Catchment Management: A UK Perspective. In Unknown Host Publication Title; John Wiley \& Sons Ltd: Chichester, UK, 1992. 
5. Gleick, P.H. Global Freshwater Resources: Soft-Path Solutions for the 21st Century. Science 2003, 302, 1524-1528. [CrossRef]

6. Allan, J.D. Landscapes and Riverscapes: The Influence of Land Use on Stream Ecosystems. Annu. Rev. Ecol. Evol. Syst. 2004, 35, 257-284. [CrossRef]

7. $\quad$ Dudgeon, D.; Arthington, A.H.; Gessner, M.O.; Kawabata, Z.-I.; Knowler, D.J.; Lévêque, C.; Naiman, R.J.; Prieur-Richard, A.-H.; Soto, D.; Stiassny, M.L.J.; et al. Freshwater Biodiversity: Importance, Threats, Status and Conservation Challenges. Biol. Rev. Camb. Philos. Soc. 2006, 81, 163-182. [CrossRef]

8. Stoll, S.; Breyer, P.; Tonkin, J.D.; Früh, D.; Haase, P. Scale-Dependent Effects of River Habitat Quality on Benthic Invertebrate Communities-Implications for Stream Restoration Practice. Sci. Total Environ. 2016, 553, 495-503. [CrossRef]

9. European Environmental Agency. European Waters: Assessment of Status and Pressures 2018; Report I No 7/2018; European Environmental Agency: Copenhagen, Denmark, 2018; p. 90.

10. Bednarek, A.T. Undamming Rivers: A Review of the Ecological Impacts of Dam Removal. Environ. Manag. 2001, 27, 803-814. [CrossRef]

11. Cooper, A.R.; Infante, D.M.; Daniel, W.M.; Wehrly, K.E.; Wang, L.; Brenden, T.O. Assessment of Dam Effects on Streams and Fish Assemblages of the Conterminous USA. Sci. Total Environ. 2017, 586, 879-889. [CrossRef]

12. Hazel, J.E., Jr.; Topping, D.J.; Schmidt, J.C.; Kaplinski, M. Influence of a Dam on Fine-Sediment Storage in a Canyon River. J. Geophys. Res. F Earth Surface 2006, 111. [CrossRef]

13. Drinkwater, K.F.; Frank, K.T. Effects of River Regulation and Diversion on Marine Fish and Invertebrates. Aquat. Conserv. Mar. Freshw. Ecosyst. 1994, 4, 135-151. [CrossRef]

14. Stanford, J.A.; Ward, J.V.; Liss, W.J.; Frissell, C.A.; Williams, R.N.; Lichatowich, J.A.; Coutant, C.C. A General Protocol for Restoration of Regulated Rivers. Regul. Rivers-Res. Manag. 1996, 12, 391-413. [CrossRef]

15. Heiring, D.; Plachter, H. Riparian Ground Beetles (Coeloptera, Carabidae) Preying on Aquatic Invertebrates: A Feeding Strategy in Alpine Foodplains. Oecologia 1997, 111, 261-270. [CrossRef]

16. Voulvoulis, N.; Arpon, K.D.; Giakoumis, T. The EU Water Framework Directive: From Great Expectations to Problems with Implementation. Sci. Total Environ. 2017, 575, 358-366. [CrossRef]

17. Bernhardt, E.S.; Palmer, M.A.; Allan, J.D.; Alexander, G.; Barnas, K.; Brooks, S.; Carr, J.; Clayton, S.; Dahm, C.; FollstadShah, J.; et al. Synthesizing U.S. River Restoration Efforts. Science 2005, 308, 636-637. [CrossRef]

18. Smith, B.; Clifford, N.J.; Mant, J. The Changing Nature of River Restoration. WIREs Water 2014, 1, 249-261. [CrossRef]

19. Verdonschot, R.C.M.; Kail, J.; McKie, B.G.; Verdonschot, P.F.M. The Role of Benthic Microhabitats in Determining the Effects of Hydromorphological River Restoration on Macroinvertebrates. Hydrobiologia 2016, 769, 55-66. [CrossRef]

20. Hobbs, R.; Cramer, V. Restoration Ecology: Interventionist Approaches for Restoring and Maintaining Ecosystem Function in the Face of Rapid Environmental Change. Annu. Rev. Environ. Resour. 2008, 33, 39-61. [CrossRef]

21. Suding, K.N. Toward an Era of Restoration in Ecology: Successes, Failures, and Opportunities Ahead. Annu. Rev. Ecol. Evol. Syst. 2011, 42, 465-487. [CrossRef]

22. Palmer, M.A.; Bernhardt, E.S.; Allan, J.D.; Lake, P.S.; Alexander, G.; Brooks, S.; Carr, J.; Clayton, S.; Dahm, C.N.; Shah, J.F.; et al. Standards for Ecologically Successful River Restoration. J. Appl. Ecol. 2005, 42, 208-217. [CrossRef]

23. Bernhardt, E.S.; Palmer, M.A. Restoring Streams in an Urbanizing World. Freshw. Biol. 2007, 52, 738-751. [CrossRef]

24. Miller, S.W.; Budy, P.; Schmidt, J.C. Quantifying Macroinvertebrate Responses to In-Stream Habitat Restoration: Applications of Meta-Analysis to River Restoration. Restor. Ecol. 2010, 18, 8-19. [CrossRef]

25. Kail, J.; Hering, D. The Influence of Adjacent Stream Reaches on the Local Ecological Status of Central European Mountain Streams. River Res. Appl. 2009, 25, 537-550. [CrossRef]

26. Palmer, M.A.; Menninger, H.L.; Bernhardt, E. River Restoration, Habitat Heterogeneity and Biodiversity: A Failure of Theory or Practice? Freshw. Biol. 2010, 55, 205-222. [CrossRef]

27. England, J.; Wilkes, M.A. Does River Restoration Work? Taxonomic and Functional Trajectories at Two Restoration Schemes. Sci. Total Environ. 2018, 618, 961-970. [CrossRef]

28. Mondy, C.P.; Villeneuve, B.; Archaimbault, V.; Usseglio-Polatera, P. A New Macroinvertebrate-Based Multimetric Index (I2M2) to Evaluate Ecological Quality of French Wadeable Streams Fulfilling the WFD Demands: A Taxonomical and Trait Approach. Ecol. Indic. 2012, 18, 452-467. [CrossRef]

29. Dolédec, S.; Forcellini, M.; Olivier, J.-M.; Roset, N. Effects of Large River Restoration on Currently Used Bioindicators and Alternative Metrics. Freshw. Biol. 2015, 60, 1221-1236. [CrossRef]

30. Teresa, F.B.; Casatti, L. Trait-Based Metrics as Bioindicators: Responses of Stream Fish Assemblages to a Gradient of Environmental Degradation. Ecol. Indic. 2017, 75, 249-258. [CrossRef]

31. Friberg, N.; Baattrup-Pedersen, A.; Kristensen, E.A.; Kronvang, B.; Larsen, S.E.; Pedersen, M.L.; Skriver, J.; Thodsen, H.; Wiberg-Larsen, P. The River Gelså Restoration Revisited: Habitat Specific Assemblages and Persistence of the Macroinvertebrate Community over an 11-Year Period. Ecol. Eng. 2014, 66, 150-157. [CrossRef]

32. Levi, P.S.; McIntyre, P.B. Ecosystem Responses to Channel Restoration Decline with Stream Size in Urban River Networks. Ecol. Appl. 2020, 30, e02107. [CrossRef]

33. Sarriquet, P.E.; Bordenave, P.; Marmonier, P. Effects of Bottom Sediment Restoration on Interstitial Habitat Characteristics and Benthic Macroinvertebrate Assemblages in a Headwater Stream. River Res. Appl. 2007, 23, 815-828. [CrossRef] 
34. Zaidel, P.A.; Roy, A.H.; Houle, K.M.; Lambert, B.; Letcher, B.H.; Nislow, K.H.; Smith, C. Impacts of Small Dams on Stream Temperature. Ecol. Indic. 2021, 120, 106878. [CrossRef]

35. Sandre-Portail National d'accès Aux Référentiels Sur l'eau. Available online: https://www.sandre.eaufrance.fr/ (accessed on 3 February 2022).

36. Graf, W.L. Geomorphology and American Dams: The Scientific, Social, and Economic Context. Geomorphology 2005, 71, 3-26. [CrossRef]

37. Csiki, S.; Rhoads, B.L. Hydraulic and Geomorphological Effects of Run-of-River Dams. Prog. Phys. Geogr. Earth Environ. 2010, 34 755-780. [CrossRef]

38. Liu, Y.; Yang, W.; Yu, Z.; Lung, I.; Yarotski, J.; Elliott, J.; Tiessen, K. Assessing Effects of Small Dams on Stream Flow and Water Quality in an Agricultural Watershed. J. Hydrol. Eng. 2014, 19. [CrossRef]

39. Fencl, J.S.; Mather, M.E.; Costigan, K.H.; Daniels, M.D. How Big of an Effect Do Small Dams Have? Using Geomorphological Footprints to Quantify Spatial Impact of Low-Head Dams and Identify Patterns of across-Dam Variation. PLoS ONE 2015, 10, e0141210. [CrossRef] [PubMed]

40. Poff, N.L.; Hart, D.D. How Dams Vary and Why It Matters for the Emerging Science of Dam Removal: An Ecological Classification of Dams Is Needed to Characterize How the Tremendous Variation in the Size, Operational Mode, Age, and Number of Dams in a River Basin Influences the Potential for Restoring Regulated Rivers via Dam Removal. BioScience 2002, 52, 659-668. [CrossRef]

41. Bailey, R.C.; Norris, R.H.; Reynoldson, T.B. The reference condition approach. In Bioassessment of Freshwater Ecosystems; Springer: Boston, MA, USA, 2004; pp. 1-15. ISBN 978-1-4419-8885-0. [CrossRef]

42. Roni, P.; Hanson, K.; Beechie, T. Global Review of the Physical and Biological Effectiveness of Stream Habitat Rehabilitation Techniques. N. Am. J. Fish. Manag. 2008, 28, 856-890. [CrossRef]

43. Barnes, J.B.; Vaughan, I.P.; Ormerod, S.J. Reappraising the Effects of Habitat Structure on River Macroinvertebrates. Freshw. Biol. 2013, 58, 2154-2167. [CrossRef]

44. Clapcott, J.E.; Collier, K.J.; Death, R.G.; Goodwin, E.O.; Harding, J.S.; Kelly, D.; Leathwick, J.R.; Young, R.G. Quantifying Relationships between Land-Use Gradients and Structural and Functional Indicators of Stream Ecological Integrity. Freshw. Biol. 2012, 57, 74-90. [CrossRef]

45. Kail, J.; Brabec, K.; Poppe, M.; Januschke, K. The Effect of River Restoration on Fish, Macroinvertebrates and Aquatic Macrophytes: A Meta-Analysis. Ecol. Indic. 2015, 58, 311-321. [CrossRef]

46. Lepori, F.; Palm, D.; Brännäs, E.; Malmqvist, B. Does Restoration of Structural Heterogeneity in Streams Enhance Fish and Macroinvertebrate Diversity? Ecol. Appl. 2005, 15, 2060-2071. [CrossRef]

47. Louhi, P.; Mykrä, H.; Paavola, R.; Huusko, A.; Vehanen, T.; Mäki-Petäys, A.; Muotka, T. Twenty Years of Stream Restoration in Finland: Little Response by Benthic Macroinvertebrate Communities. Ecol. Appl. 2011, 21, 1950-1961. [CrossRef]

48. Birk, S.; Bonne, W.; Borja, A.; Brucet, S.; Courrat, A.; Poikane, S.; Solimini, A.; van de Bund, W.; Zampoukas, N.; Hering, D. Three Hundred Ways to Assess Europe's Surface Waters: An Almost Complete Overview of Biological Methods to Implement the Water Framework Directive. Ecol. Indic. 2012, 18, 31-41. [CrossRef]

49. Wright, J.F.; Furse, M.T.; Moss, D. River Classification Using Invertebrates: RIVPACS Applications. Aquat. Conserv. Mar. Freshw. Ecosyst. 1998, 8, 617-631. [CrossRef]

50. Morandi, B.; Piégay, H.; Lamouroux, N.; Vaudor, L. How Is Success or Failure in River Restoration Projects Evaluated? Feedback from French Restoration Projects. J. Environ. Manag. 2014, 137, 178-188. [CrossRef]

51. Villeneuve, B.; Souchon, Y.; Usseglio-Polatera, P.; Ferréol, M.; Valette, L. Can We Predict Biological Condition of Stream Ecosystems? A Multi-Stressors Approach Linking Three Biological Indices to Physico-Chemistry, Hydromorphology and Land Use. Ecol. Indic. 2015, 48, 88-98. [CrossRef]

52. Corneil, D.; Villeneuve, B.; Piffady, J.; Chandesris, A.; Usseglio-Polatera, P.; Souchon, Y. Introducing Nested Spatial Scales in Multi-Stress Models: Towards Better Assessment of Human Impacts on River Ecosystems. Hydrobiologia 2018, 806, 347-361. [CrossRef]

53. Wiederkehr, J.; Grac, C.; Fontan, B.; Labat, F.; Le Ber, F.; Trémolières, M. Experimental Study of the Uncertainty of the Intrasubstrate Variability on Two French Index Metrics Based on Macroinvertebrates. Hydrobiologia 2016, 779, 59-73. [CrossRef]

54. Mondy, C.P.; Usseglio-Polatera, P. Using Conditional Tree Forests and Life History Traits to Assess Specific Risks of Stream Degradation under Multiple Pressure Scenario. Sci. Total Environ. 2013, 461-462, 750-760. [CrossRef]

55. Mondy, C.P.; Dézerald, O.; Bonne, C.; Usseglio-Polatera, P. Multi-Component Ecological Diagnosis of Rivers; Progress Report Year 1; University of Lorraine (LIEC) for the French Biodiversity Agency (AFB): Nancy, France, 2017; 96p.

56. Piscart, C.; Genoel, R.; Doledec, S.; Chauvet, E.; Marmonier, P. Effects of Intense Agricultural Practices on Heterotrophic Processes in Streams. Environ. Pollut. 2009, 157, 1011-1018. [CrossRef]

57. CORINE Land Cover I Données et Études Statistiques. Available online: https://www.statistiques.developpement-durable.gouv. $\mathrm{fr}$ / corine-land-cover-0 (accessed on 3 February 2022).

58. AFNOR Qualité de l'eau—Prélèvement Des Macro Invertébrés Aquatiques En Rivières Peu Profondes. XP T90-333. DREAL 2009, 22. Available online: https://www.sandre.eaufrance.fr/?urn=urn:sandre:donnees:MET::CdMethode:1221:::referentiel:2:html (accessed on 3 February 2022).

59. Armitage, P.D.; Moss, D.; Wright, J.F.; Furse, M.T. The Performance of a New Biological Water Quality Score System Based on Macroinvertebrates over a Wide Range of Unpolluted Running-Water Sites. Water Res. 1983, 17, 333-347. [CrossRef] 
60. Gabriels, W.; Lock, K.; De Pauw, N.; Goethals, P.L.M. Multimetric Macroinvertebrate Index Flanders (MMIF) for Biological Assessment of Rivers and Lakes in Flanders (Belgium). Limnologica 2010, 40, 199-207. [CrossRef]

61. Shannon, C.E. A Mathematical Theory of Communication. Bell Syst. Tech. J. 1948, 27, 379-423. [CrossRef]

62. Dolédec, S.; Statzner, B. Invertebrate Traits for the Biomonitoring of Large European Rivers: An Assessment of Specific Types of Human Impact. Freshw. Biol. 2008, 53, 617-634. [CrossRef]

63. Fox, J.; Weisberg, S. An R Companion to Applied Regression; SAGE Publications, Inc.: Thousand Oaks, CA, USA, 2019; ISBN 978-14129-7514-8.

64. French Ministry of Ecology and Sustainable Development. SEQ-Eau Version 2 Stream Water Quality Assessment System; Ministère de l'Écologie et du Développement Durable (French Ministry of Ecology and Sustainable Development): Paris, France, 2003; 40p. Available online: https:/ / rhin-meuse.eaufrance.fr/IMG/pdf/grilles-seq-eau-v2.pdf (accessed on 7 February 2022).

65. Thioulouse, J.; Dray, S.; Dufour, A.-B.; Siberchicot, A.; Jombart, T.; Pavoine, S. Multivariate Analysis of Ecological Data with Ade4, 1st ed.; Springer: New York, NY, USA, 2018; ISBN 978-1-4939-8848-8.

66. Bates, D.; Mächler, M.; Bolker, B.; Walker, S. Fitting Linear Mixed-Effects Models Using Lme4. J. Stat. Softw. 2015, 67, 1-48. [CrossRef]

67. Lenth, R.V. Emmeans: Estimated Marginal Means, Aka Least-Squares Means; R Package Version 1.6.0.; R Foundation for Statistical Computing: Vienna, Austria, 2022. Available online: https://CRAN.R-project.org/package=emmeans (accessed on 20 January 2022).

68. Woolsey, S.; Capelli, F.; Gonser, T.; Hoehn, E.; Hostmann, M.; Junker, B.; Paetzold, A.; Roulier, C.; Schweizer, S.; Tiegs, S.D.; et al. A Strategy to Assess River Restoration Success. Freshw. Biol. 2007, 52, 752-769. [CrossRef]

69. Jähnig, S.C.; Lorenz, A.W.; Hering, D.; Antons, C.; Sundermann, A.; Jedicke, E.; Haase, P. River Restoration Success: A Question of Perception. Ecol. Appl. 2011, 21, 2007-2015. [CrossRef]

70. Pander, J.; Geist, J. Ecological Indicator for Stream Restoration Success. Ecol. Indic. 2013, 30, 106-118. [CrossRef]

71. Stirling, G.; Wilsey, B. Empirical Relationships between Species Richness, Evenness, and Proportional Diversity. Am. Nat. 2001, 158, 286-299. [CrossRef] [PubMed]

72. Mendes, R.S.; Evangelista, L.R.; Thomaz, S.M.; Agostinho, A.A.; Gomes, L.C. A Unified Index to Measure Ecological Diversity and Species Rarity. Ecography 2008, 31, 450-456. [CrossRef]

73. Palmer, M.; Hakenkamp, C.C.; Nelson-Baker, K. Ecological Heterogeneity in Streams: Why Variance Matters. J. N. Am. Benthol. Soc. 1997, 16, 189-202. [CrossRef]

74. Vörösmarty, C.J.; McIntyre, P.B.; Gessner, M.O.; Dudgeon, D.; Prusevich, A.; Green, P.; Glidden, S.; Bunn, S.E.; Sullivan, C.A.; Liermann, C.R.; et al. Global Threats to Human Water Security and River Biodiversity. Nature 2010, 467, 555-561. [CrossRef] [PubMed]

75. Mondy, C.P.; Muñoz, I.; Dolédec, S. Life-History Strategies Constrain Invertebrate Community Tolerance to Multiple Stressors: A Case Study in the Ebro Basin I Elsevier Enhanced Reader. Available online: https:/ / reader.elsevier.com/reader/sd/pii/S0048969 716316813?token=5BC95E54DD5030A48D4F3D67661D2EB941063D2C31AB2E23358AC7AED0DF19CBC91BE47ECC7042DDB6 A536221FE5D5D2\&originRegion=eu-west-1\&originCreation=20210712091357 (accessed on 12 July 2021).

76. Piscart, C.; Navel, S.; Maazouzi, C.; Montuelle, B.; Cornut, J.; Mermillod-Blondin, F.; des Chatelliers, M.C.; Simon, L.; Marmonier P. Leaf Litter Recycling in Benthic and Hyporheic Layers in Agricultural Streams with Different Types of Land Use. Sci. Total Environ. 2011, 409, 4373-4380. [CrossRef]

77. Beschta, R.L.; Jackson, W.L. The Intrusion of Fine Sediments into a Stable Gravel Bed. J. Fish. Res. Board Can. 1979, 36, 204-210. [CrossRef]

78. Gayraud, S.; Philippe, M. Does Subsurface Interstitial Space Influence General Features and Morphological Traits of the Benthic Macroinvertebrate Community in Streams? Arch. Hydrobiol. 2001, 151, 667-686. [CrossRef]

79. Roy, A.H.; Rosemond, A.D.; Paul, M.J.; Leigh, D.S.; Wallace, J.B. Stream Macroinvertebrate Response to Catchment Urbanisation (Georgia, U.S.A.): Catchment Urbanisation and Macroinvertebrates. Freshw. Biol. 2003, 48, 329-346. [CrossRef]

80. Moerke, A.H.; Lamberti, G.A. Restoring Stream Ecosystems: Lessons from a Midwestern State. Restor. Ecol. 2004, 12, 327-334. [CrossRef]

81. Kail, J.; Arle, J.; Jähnig, S.C. Limiting Factors and Thresholds for Macroinvertebrate Assemblages in European Rivers: Empirical Evidence from Three Datasets on Water Quality, Catchment Urbanization, and River Restoration. Ecol. Indic. 2012, $18,63-72$. [CrossRef]

82. Ippolito, A.; Sala, S.; Faber, J.H.; Vighi, M. Ecological Vulnerability Analysis: A River Basin Case Study. Sci. Total Environ. 2010, 408, 3880-3890. [CrossRef] [PubMed]

83. Friberg, N.; Sandin, L.; Pedersen, M.L. Assessing the Effects of Hydromorphological Degradation on Macroinvertebrate Indicators in Rivers: Examples, Constraints, and Outlook. Integr. Environ. Assess. Manag. 2009, 5, 86. [CrossRef] [PubMed] 